\title{
Expression, Purification and Characterization of Recombinant Histidine-tagged L-asparaginase II
}

Zeinat K. Mohamed, Sh.M. Elnagdy ${ }^{*}$ and M.Gamal

Botany and Microbiology Department, Faculty of Science, Cairo University, Egypt

\begin{abstract}
F SCHERICHIA coli has two L-asparaginase isozymes that have been designated L-asparaginase I and L-asparaginase II. The amino acid sequences of both are rather dissimilar except for a few regions of significant homology. The sequence corresponding to the mature (ansB) was subcloned into pQE-30 expression vector and expressed in E. coli M15. The recombinant histidine-tagged (ansB) was purified to homogeneity by $\mathrm{Ni}-\mathrm{NTA}$ affinity chromatography and displayed a single $36.0 \mathrm{kDa}$ band on SDS-PAGE. Results revealed that the recombinant His-tagged L-ASNase II was expressed in an active form and its specific activity was estimated to be $286 \mathrm{U} / \mathrm{mg}$. The optimum temperature was attained at $40^{\circ} \mathrm{C}$. The enzyme was maximum at $\mathrm{pH} 7-8$. Also the enzyme was stable at $40-50^{\circ} \mathrm{C}$. The purified functional enzyme exhibited a specific activity at $286 \mathrm{U} / \mathrm{mg}$ and inhibited the growth of human myeloid leukemia cell line (HL-60) with $\mathrm{IC}_{50}$ value of $0.14 \pm 0.03 \mathrm{U} / \mathrm{ml}$.
\end{abstract}

Keywords: Anti-tumor, Cytotoxicity, Expression, His-tag, LAsparaginase, Leukemia, Purification, Recombinant.

Studying, L-Asparaginase (L-ASNase) has recently gained much attention for its anti-carcinogenic potential due to their high catalytic activity and specificity towards L-asparagine (Duval et al., 2002). Beside its therapeutic use, L-ASNase has been used in food industry to reduce acrylamide formation in heat-processed products (Pedreschi et al., 2008 and Kukurová et al., 2013).

Escherichia coli was found to have two L-asparaginase isozymes that were named L-asparaginase I and L-asparaginase II. Only L-asparaginase II exhibited tumor inhibitory activity, so it has been extensively studied. Trials were conducted to identify microbial sources for L-asparaginase, since its extraction and purification from the guinea pig serum was insufficient. L-asparaginase was isolated and purified from Escherichia coli. It was efficient in treatment of the children suffering from acute lymphoblastic leukemia and demonstrated a similar anti-tumor activity to that of guinea pig sera (Jerlstörm et al., 1989).

The anti-neoplastic activity of L-asparaginases is mainly due to the selective depletion of L-asparagine in the blood serum. Unlike normal cells, certain lymphosarcomas and the leukocytes transformed in acute lymphoblastic leukemia (ALL) cannot compensate for the lack of asparagine, because they show a diminished expression of asparagine synthetase. Therefore, these cells

*Corresponding author: Dr. Sherif Elnagdy e-mail:sh.elnagdy@gmail.com 
depend on an extracellular supply of L-asparagine, which they obtain from the circulating pools, for their proliferation. Intravenous treatment with Lasparaginase leads to depletion of the supply of L-asparagine and can thus be cytotoxic for the neoplastic cells causing its selective death. In contrast, normal cells are protected from L-asparagine-starvation due to their ability to synthesize this amino acid in amounts sufficient for their metabolic needs with their own enzyme, L-asparagine synthetase. This behavior of cancer cells was the key of treatment leukemia using L-asparaginase. The cure rate has now improved to $80 \%$ in children and $30-40 \%$ in adults using L-asparaginase in combination with other existing drugs (Narta et al., 2007 and Sreenivasulu et al., 2009).

The purification of recombinant proteins can be improved by using affinity tags. These tags are fused to the protein of interest and used for purification of the tagged proteins selectively via affinity chromatography. This method utilizes immobilized metal-affinity chromatography (IMAC) to purify recombinant proteins containing a short affinity tag of polyhistidine residues. IMAC is based on interactions between an immobilized transition metal ion such as $\mathrm{Ni}^{2+}$ - and specific amino acid side chains. Histidine exhibits the strongest interaction with immobilized metal ion matrices. (Terpe, 2003).

Polyhistidine tagged proteins can be purified rapidly by IMAC method resulting in about 100 folds enrichment in a single purification step. Affinitytagged protein purities can be achieved at up to $95 \%$ purity by IMAC in high yield. The His-tag combines the advantages of being inert, of low immunogenicity, and of small size $(0.84 \mathrm{kDa})$. Purification using polyhistidine tags was carried out successfully using a number of expression systems, including Escherichia coli, Saccharomyces cerevisiae, Pichia pastoris, mammalian cells, and baculovirus-infected insect cells (Zakalskiy et al, 2012; Sockolosky and Szoka, 2013).

The relatively small size and charge of the His-tag ensure that protein activity is rarely affected. Usually, the affinity tag does not need to be removed following protein purification. But if necessary, the affinity tag can be removed by inserting a protease cleavage site in between the tag and the protein. Some of the commonly used cleavage enzymes include the tobacco etch virus (TEV) protease, thrombin, enterokinase (EK), and factor Xa (fXa), which all belong to the protease class of endopeptidases. Polyhistidine affinity tags are small enough to be incorporated easily into any expression vector by PCR methods. DNA nucleotides coding for the polyhistidine affinity tag can also be created from synthetic oligonucleotides and cloned into an appropriate location in the desired plasmid. Alternatively, there are a wide variety of commercially available expression vectors for expression of polyhistidine-tagged recombinant proteins in different expression systems (Rabbani et al., 2010 and Shuguo et al., 2012).

Wide variety of immobilized metal matrices is available for use in IMAC. The three-dentate ligand iminodiacetic acid (IDA) was used initially as a matrix for chelating transition metals through three coordination sites. A problem with

Egypt. J. Bot., Vol. 56, No. 3 (2016) 
the use of IDA matrices is that the metal ion is only weakly bound to this threecoordinate matrix. Metal leaching from the matrix during purification results in lowered yields and impure products. More recently, purification of His-tagged proteins has been facilitated by the development of the commercially available matrices nickel-nitrilotriacetic acid $\left(\mathrm{Ni}^{2+}-\mathrm{NTA}\right)$. It is tetradentate ligand that binds the metal ion with extra carboxylate oxygen compared to IDA. This could give it a superior metal chelating strength (Feng et al., 2010).

There have been many attempts for cloning and expression of L-asparaginase (ansB) gene from different microorganisms. Wang et al. (2001) cloned DNA fragment coding for L-asparaginase from $E$. coli AS1.357 into the expression vector pBV220 and transformed into E. coli strains JM105, JM109, TG1, DH5 $\alpha$ and AS1.357. The subunit molecular weight of the expressed enzyme was 36,000 Daltons by sodium dodecyl sulfate polyacrylamide gel electrophoresis (SDS-PAGE). The recombinant plasmid in E. coli AS1.357 remained stable after $72 \mathrm{hr}$ of cultivation and $5 \mathrm{hr}$ of heat induction without selective pressure.

Vidya and Pandey (2012) cloned L-asparaginase II gene that isolated from a moderately thermo-tolerant bacterium belonging to Enterobacteriaceae into pET20b expression vector with a six histidine sequences at the C-terminal end transformed to competent BL21 DE3 cells. The histidine-tagged protein (Histagged) was purified through nickel affinity chromatography using Ni-NTA spin column. The purified protein showed optimum activities at a temperature of $37^{\circ} \mathrm{C}$ and in a buffer system of $\mathrm{pH} 6$ to 7 . The cloned gene showed $99 \%$ similarity with L-asparaginase type II of E. coli KO11.

In the case of expression of L-asparaginase from Erwinia chrysanthemi 3937 in $E$. coli BL21, the expressed recombinant enzyme was purified to homogeneity in a single-step procedure involving cation exchange chromatography on an SSepharose FF column (Kotzia and Labrou, 2007). The sequence of the cloned ans $B$ gene from the pathogenic strain Helicobacter pylori (993 bp) was subcloned into the pET101 expression vector and transformed to E. coli BL21 (DE3) competent cells. The recombinant enzyme purified to homogeneity displayed a single $37 \mathrm{kDa}$ band on a 12\% SDS-PAGE (Cappelletti et al., 2008).

In this study, the sequence corresponding to the mature L-ASNase II was subcloned into pQE-30 expression vector and expressed in E. coli M15. The recombinant histidine-tagged L-ASNase II was purified to homogeneity by $\mathrm{Ni}-$ NTA affinity chromatography and displayed on SDS-PAGE. The cytotoxic activity of recombinant L-asparaginase II was assayed and characterization of recombinant L-asparaginase II was conducted.

\section{Materials and Methods}

\section{Preparation of plasmid}

To prevent self-ligation of plasmid, the terminal 5'-phosphate groups should be removed by using alkaline phosphatase. This dephosphorylation reaction

Egypt. J. Bot., Vol. 56, No. 3 (2016) 
suppresses self-ligation of vector molecules and decreases the number of empty vectors. The insert DNA with intact 5'-terminal phosphate residues can be ligated efficiently into the dephosphorylated plasmid DNA.

pQE-30 vector was double digested and dephosphorylated using FastDigest BamHI and HindIII restriction enzymes simultaneously with FastAP Thermosensitive Alkaline Phosphatase according to protocol recommended by the manufacturer. The reaction mixture contained $1 \mu \mathrm{g}$ of pQE-30 vector, $2 \mu \mathrm{l}$ of 10X Thermo Scientific FastDigest Buffer, $1 \mu \mathrm{l}$ of FastDigest BamHI, $1 \mu 1$ of FastDigest HindIII restriction enzymes, $1 \mu$ l of FastAP Thermosensitive Alkaline Phosphatase and nuclease-free water up to $20 \mu$. The reaction components were mixed thoroughly and incubated at $37^{\circ} \mathrm{C}$ for $10 \mathrm{~min}$. The reactions were stopped by heating at $80^{\circ} \mathrm{C}$ for 20 minutes and electrophoresed into $1 \%$ agarose gel in $1 \mathrm{X}$ TAE runing buffer for $60 \mathrm{~min}$ at $50 \mathrm{~V}$. Then the band of the double digested dephosphorylated plasmid was gel purified as described previously. Gel purified double digested dephosphorylated plasmid DNA was used for subcloning and expression of ans $B$ gene.

Subcloning of ans B gene

L-asparaginase II gene was subcloned into $\mathrm{pQE}-30$ expression vector. DNA insert was positioned downstream and in frame with a sequence that encodes an $\mathrm{N}$-terminal fusion peptide, a series of six histidine residues that function as a metal binding domain in the translated recombinant protein.

For subcloning of ans $B$ gene into $\mathrm{pQE}-30$ expression vector, a ligation reaction was conducted in an $20 \mu \mathrm{l}$ final volume comprising one $\mu \mathrm{l}$ dephosphorylated plasmid DNA previously digested with BamHI-HindIII, $2 \mu \mathrm{l}$ ligase buffer (10x), one $\mu 1$ T4 DNA ligase (Thermo Scientific, USA), and the insert previously released from pGEM-ansB construct by double digestion with $B a m \mathrm{HI}$ and HindIII. The reaction mixture was brought to the final volume with sterile nuclease-free water and incubated at $22^{\circ} \mathrm{C}$ for $10 \mathrm{~min}$. For an efficient ligation reaction the amount of plasmid vector was one third of the insert. The resultant plasmid was referred to as $\mathrm{pQE}$-ansB and used for transformation of $E$. coli M15 competent cells.

E. coli M15 competent cells were transformed by heat-shock treatment essentially as described by Sambrook and Russel (2001). After transformation into $E$. coli strain M15, clones with correct inserts were checked by colony PCR using vector-specific primers.Positive clones were confirmed by colony PCR according to method described by Güssow and Clackson (1989) with some modifications. PCR product sizes were checked by $1 \%$ agarose gel electrophoresis. The positive clones that showed correct PCR product sizes were selected.

\section{Expression of ansB gene}

Transformed E. coli $\mathrm{M} 15$ cells were cultured overnight at $37^{\circ} \mathrm{C}$ in $5 \mathrm{ml}$ of $\mathrm{LB}$ broth containing $100 \mu \mathrm{g} / \mathrm{ml}$ ampicillin and $25 \mu \mathrm{g} / \mathrm{ml}$ kanamycin under vigorous

Egypt. J. Bot., Vol. 56, No. 3 (2016) 
agitation (200 rpm). This pre-inoculum suspension was then used to inoculate $500 \mathrm{ml}$ fresh LB selection medium, which was agitated until an O.D. 600 reached 0.6. Thereafter, an aliquot of non-induced control cells was collected and reserved for sodium dodecyl sulfate polyacrylamide gel electrophoresis (SDSPAGE) analysis. Expression of His-tagged L-asparaginase II was induced in the left cells by addition of IPTG to a final concentration of $0.4 \mathrm{mM}$. The cells were cultivated at $37^{\circ} \mathrm{C}$ for $3 \mathrm{hr}$ in the induction medium and afterwards collected by centrifugation at $7,000 \times \mathrm{g}$ at $4^{\circ} \mathrm{C}$ for $20 \mathrm{~min}$. The resultant pellets were stored at $-20^{\circ} \mathrm{C}$.

The bacterial pellets were thawed on ice for 15 minutes and resuspended in lysis buffer ( $50 \mathrm{mM} \mathrm{NaH} \mathrm{PO}_{4}, 300 \mathrm{mM} \mathrm{NaCl}$, and $10 \mathrm{mM}$ imidazole, $\mathrm{pH} 8.0$ ) and incubated on ice for $30 \mathrm{~min}$. Cells were sonicated for 6 cycles (10 s bursts at 200 Watt with a $10 \mathrm{~s}$ cooling period between each burst). The cell lysate was centrifuged at $10,000 \times \mathrm{g}$ for $20 \mathrm{~min}$. at $4^{\circ} \mathrm{C}$ and $50 \mu \mathrm{l}$ cleared lysate supernatant was stored at $-20^{\circ} \mathrm{C}$ for SDS-PAGE analysis.

\section{Purification of recombinant ansB gene}

The cell lysate supernatant was purified under native conditions using NiNTA resin (Qiagen, Hilden, Germany) following the manufacturer's protocol. Fraction containing recombinant L-asparaginase II was dialyzed by phosphate buffered saline (PBS) and was analyzed by SDS-PAGE and enzyme assay was performed.

Protein expression and purification processes were examined with SDSPAGE. Protein samples separated on $12 \%$ SDS-PAGE gels. Proteins were denatured in the presence of SDS and 2-mercaptoethanol as thiol reducing agent. Gels were stained with Coomassie stain and the protein sizes were determined by comparing the migration of the protein band to a molecular mass standard (Roti ${ }^{\circledR}$-Mark STANDARD protein marker, Carl Roth $\mathrm{GmbH}$ and Co. KG, Karlsruhe, Germany).

SDS-PAGE was conducted according to standard protocols (Sambrook and Russel, 2001). Samples containing the supernatant were mixed with equal amount of $2 \mathrm{X}$ sample buffer and boiled for $5 \mathrm{~min}$. followed by centrifugation at maximum speed for $5 \mathrm{~min}$. to settle down insoluble materials. The supernatant was used as sample for SDS-PAGE.

\section{Characterization of recombinant L-asparaginase II}

The effect of temperature on recombinant L-asparaginase II activity was assayed at temperatures in the range from 30 to $80^{\circ} \mathrm{C}$ at $\mathrm{pH}$ 8.6. The effect of different $\mathrm{pH}$ values on recombinant L-asparaginase II activity was assayed. The enzymatic activity was assessed using different buffers with different $\mathrm{pH}$ values ranging from $\mathrm{pH} 3.0$ to 10.0 . In the $\mathrm{pH}$ range from 3 to 5.5 , a $50 \mathrm{mM}$ sodium acetate-acetic acid buffer was used, in the $\mathrm{pH}$ range from 6 to 8 , a $50 \mathrm{mM}$ phosphate buffer was used and in the $\mathrm{pH}$ range from 8.5 to 10.0 , a $50 \mathrm{mM}$ carbonate buffer was used. Thermal stability was assessed by incubation of 
recombinant L-asparaginase II at 40 to $80^{\circ} \mathrm{C}$ in $0.05 \mathrm{M}$ phosphate buffer (pH 8.6) for $60 \mathrm{~min}$. Subsequently, the samples were assayed for residual activity. The residual activity was calculated by comparing the activity to that of the untreated control enzyme, which is taken as $100 \%$.

\section{Cytotoxic activity of recombinant L-asparaginase II}

Human myeloid leukemia HL-60 cells were cultured in suspension in RPMI1640 medium supplemented with $10 \%$ fetal bovine serum, $100 \mathrm{U} / \mathrm{ml}$ penicillin and $100 \mu \mathrm{g} / \mathrm{ml}$ streptomycin. Cells were incubated at $37^{\circ} \mathrm{C}$ in a humidified atmosphere of 5\% $\mathrm{CO}_{2}$ in air. Cells were split every 3-4 days to maintain in an exponential growth.

HL-60 cells were seeded in each well containing $100 \mu \mathrm{l}$ of RPMI-1640 medium in 96-well plates at $5 \times 10^{4}$ cells/well. After $24 \mathrm{hr}$, different Lasparaginase II levels ranging from 0.001 to $2.0 \mathrm{U} / \mathrm{ml}$ were added. Cells were kept in culture for $48 \mathrm{hr}$ before cell viability was assessed. The cell viability was estimated by the 3- [4,5-dimethylthiazole-2-yl]-2,5-diphenyltetrazolium bromide (MTT) assay according to Mosmann (1983). $10 \mu \mathrm{l}$ of MTT $(5 \mathrm{mg} / \mathrm{ml})$ was added to each well, the plates were incubated at $37^{\circ} \mathrm{C}$ for $4 \mathrm{hr}$. Afterwards, $100 \mu \mathrm{l}$ of acid-isopropanol (0.04 N HCI in isopropanol) was added to all wells and mixed thoroughly. The absorbance was measured within $1 \mathrm{~h}$ using an ELISA reader (BioRad, München, Germany) at $570 \mathrm{~nm}$.

All measurements were done in triplicate and cell survival was calculated by subtracting the background absorbance of media alone and then dividing the absorbance of test wells by the absorbance of the control (untreated) wells. After subtraction of blank values, the leukemic cell survival (LCS) was calculated as previously described (Pieters et al., 1990) using the equation:

\section{$\mathrm{LCS}=(\mathrm{OD}$ treated well/mean OD control wells $) \times 100$}

Additionally, the half maximal growth inhibitory concentration $\mathrm{IC}_{50}$ value was calculated. $\mathrm{IC}_{50}$ represents the inhibitory concentration required to reduce viable cell number by $50 \%$

\section{Statistical analysis}

The measured data were subjected to the analysis of variance (ANOVA) appropriate to the design. The significant differences between treatments were compared with the critical difference at 5\% level of probability by the Duncan's test using PASW 17.0 statistics software (SPSS Inc).

\section{Results}

\section{Construction of expression Vector system}

After transformation, several clones (designated ans $B-1$ to ans $B-7$ ) were picked and checked for successful ligation by colony PCR using primers designed for pQE-30. Clones which produced an amplicon of about $1 \mathrm{~kb}$

Egypt. J. Bot., Vol. 56, No. 3 (2016) 
indicated positive transformants. Six colonies (lanes 1, 2, 3, 4, 6 and 7) were clearly found to be positive for recombinant plasmid carrying ans $B$ gene as shown in Fig. 1. Clone ans $B-4$ carrying pQE-ans $B$ construct was selected for production of recombinant histidine-tagged L-asparaginase II.

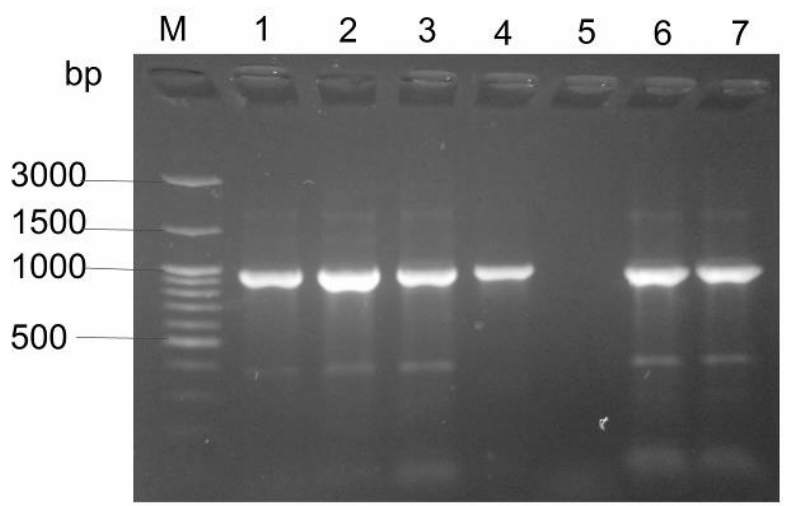

Fig. 1. Screening of transformants containing $\mathrm{pQE}$-ansB by colony PCR. Lane M, DNA ladder; lanes 1-7: ans $B-1$ to ans $B-7$ clones. Individual bacterial colonies were picked from LB/ampicillin/ kanamycin plates, resuspended in $100 \mu \mathrm{l}$ sterile nuclease-free water and boiled. After centrifugation, 1-2 $\mu \mathrm{l}$ of the supernatant was used as a template in the PCR using vector-specific primers. PCR products were analyzed on $1 \%$ agarose gel electrophoresis. Lanes 1,2 , 3, 4, 6 and 7 showed PCR product of the expected size $(\sim 1 \mathrm{~kb})$ considered as successful transformants while lane 5 was unsuccessful transformant.

Overexpression and purification of His-tagged L-asparaginase II in E. coli M15

Analysis of SDS-PAGE gel revealed that a protein had been overexpressed in E.coli M15 cells contains pQE-ansB vector after induction with IPTG. The molecular weight of the overexpressed protein was $36.0 \mathrm{kDa}$. The highly purified His-tagged protein was migrated as a single band in SDS-PAGE gel as shown in Fig. 2.

Characterization of recombinant L-asparaginase II

Results revealed that the recombinant His-tagged L-ASNase II was expressed in an active form and its specific activity was estimated to be $286 \mathrm{U} / \mathrm{mg}$. Temperature activity profile showed that the enzyme was active in the temperature range of $30-60^{\circ} \mathrm{C}$ with maximum activity at $40^{\circ} \mathrm{C}$ (Fig. 3). The enzyme was found active over a broad $\mathrm{pH}$ range (4-10) with maximum activity at $\mathrm{pH} 7$ to 8 (Fig. 4). Results demonstrated that enzyme retained about $100 \%$, $81 \%$ and $44 \%$ of its initial activity after 60 min incubation at 40,50 and $60^{\circ} \mathrm{C}$, respectively (Fig. 5). Enzyme lost about $85 \%$ and $94 \%$ of its initial activity when incubated at 70 and $80^{\circ} \mathrm{C}$ for $60 \mathrm{~min}$, respectively. 


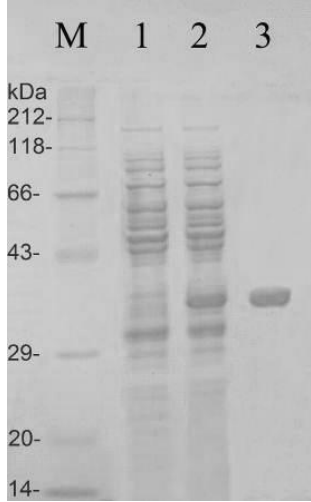

Fig. 2. SDS-PAGE showing expression and purification of His-tagged Lasparaginase II using Ni-NTA affinity chromatography. Lane M, protein marker; lane 1, total soluble proteins of uninduced cells; lane 2, total soluble proteins of induced cells; lane 3, purified His-tagged Lasparaginase II. Transformed $E$. coli M15 cells were cultured in selective LB broth until an O.D.600 reached 0.6. The expression of His-tagged Lasparaginase II was induced by addition of IPTG. After $3 \mathrm{~h}$, cells were collected and sonicated. The cell lysate supernatant was purified under native conditions using Ni-NTA affinity chromatography. Aliquots from uninduced, induced cells and purified protein were analyzed by SDSPAGE and Coomassie blue staining.

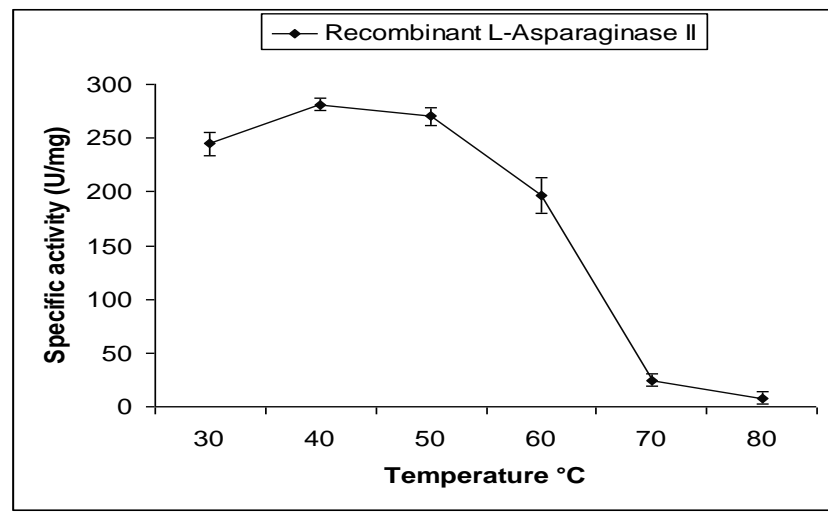

Fig. 3. Temperature profile of recombinant L-asparaginase II. The effect of temperature on the enzymatic activity of recombinant L-ASNase II was assayed at temperatures in the range from 30 to $80^{\circ} \mathrm{C}$ at $\mathrm{pH} \mathrm{8.6.}$

- Error bars represent standard deviations (SD). 


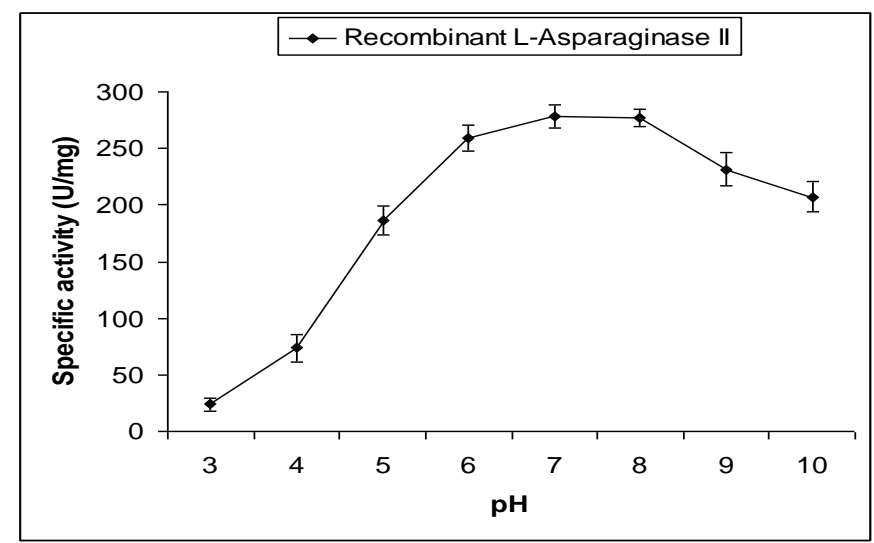

Fig. 4. pH profile of recombinant L-asparaginase II. The effect of pH on the enzymatic activity of recombinant L-ASNase II was assayed at different $\mathbf{p H}$ values ranging from $\mathrm{pH}$ 3.0 to10.0. Error bars represent standard deviations (SD).

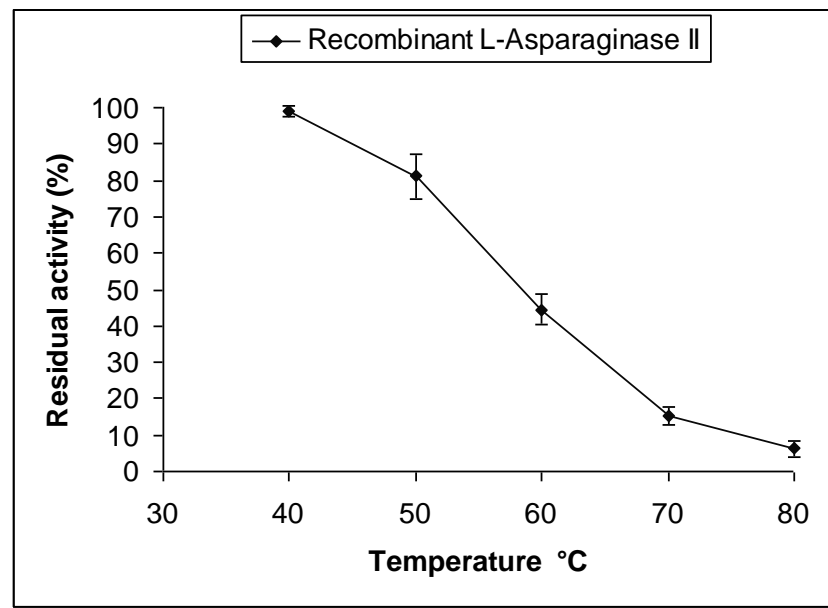

Fig. 5. Thermal stability of recombinant L-asparaginase II. Thermal stability was assessed by incubation of recombinant L-ASNase II at 40 to $80^{\circ} \mathrm{C}$ in $0.05 \mathrm{M}$ phosphate buffer ( $\mathrm{pH} 8.6$ ) for $60 \mathrm{~min}$, and then enzymatic activity was estimated. Residual activity was calculated by comparing the activity to that of the untreated control enzyme, which is taken as $100 \%$.

- $\quad$ Error bars represent standard deviations (SD).

Cytotoxic activity of recombinant L-asparaginase II

Data obtained from MTT assay indicated a strong dose-response relationship with regard to the cytotoxic activity of L-ASNase (Fig. 6). Results showed that no significant cytotoxic activity was recorded when HL-60 cells were incubated with recombinant L-ASNase in levels ranging from 0.001 to $0.01 \mathrm{U} / \mathrm{ml}$. As the 
level of enzyme increased, dramatic decrease in the LCS of HL-60 cells was observed. LCS decreased to about 52\%, 14\% and 3\% when increased levels of the recombinant enzyme $(0.1,1.0$ and $2 \mathrm{U} / \mathrm{ml}$, respectively) were applied to HL60 cell lines. The half maximal growth inhibitory concentration value $\left(\mathrm{IC}_{50}\right)$ of the recombinant L-ASNase was computed to be $0.14 \pm 0.03 \mathrm{U} / \mathrm{ml}$.

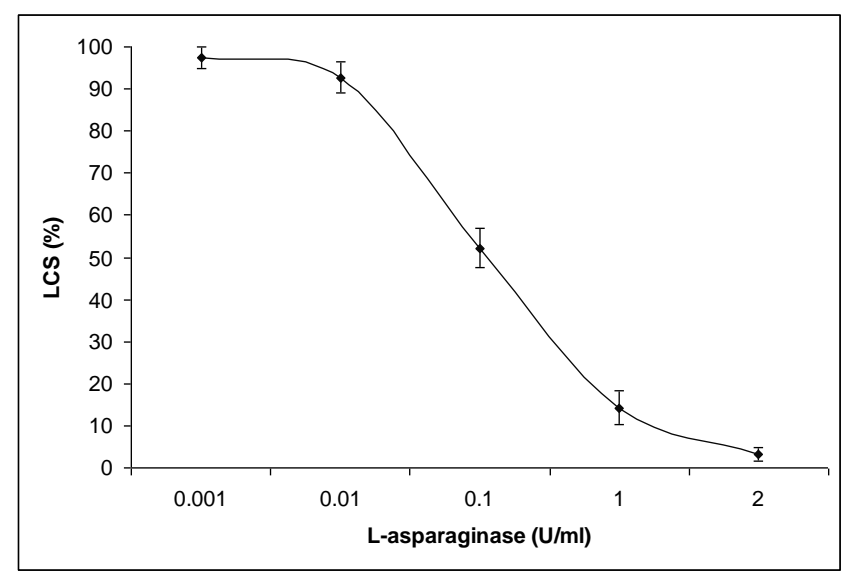

Fig. 6. Cytotoxic effect of recombinant $L$-asparaginase on cell survival in leukemia cell line. HL-60 cells were treated in triplicate with each concentration for 48 $h$ and the cell viability was determined by the MTT assay.

- Error bars represent standard deviations (SD).

\section{Discussion}

The overall objective of this study was the construction of an expression system of L-asparaginase II ( $a n s B$ ) gene in frame with $\mathrm{N}$-terminal region coding for six histidine residues to facilitate the protein purification process using immobilized metal-affinity chromatography. Accordingly, the ans $B$ gene from a local $E$. coli isolate was cloned into pQE-30 expression vector under the control of T5 inducible promoter and successfully expressed in E. coli M15 cells. The expressed functional enzyme bearing $\mathrm{N}$-terminal His-tag was purified in a single step using Ni-NTA chromatography.

With an objective to express His-tagged L-ASNase II enzyme, ansB gene was subcloned into pQE-30 expression vector in the right reading frame using Bam HI and HindIII restriction sites incorporated into the PCR fragments through $a n s B-\mathrm{F}$ and $a n s B-\mathrm{R}$ primers. ans $B$ gene was subcloned into Bam $\mathrm{HI} / H i n \mathrm{dIII}$ digested pQE-30 and subsequently transformed into $E$. coli M15 competent cells. The resulting transformants were validated for the presence of expression construct $\mathrm{pQE}-a n s B$ by colony PCR using vector specific primers. Based on colony PCR screening, clone ansB-4 harboring pQE-ans $B$ construct was selected

Egypt. J. Bot., Vol. 56, No. 3 (2016) 
for production of recombinant His-tagged L-ASNase II. L-ASNases from Escherichia coli, Erwinia carotovora, E. crysanthemi, Helicobacter pylori, Yersinia pseudotuberculosis and Bacillus subtilis was cloned and successfully expressed in various bacterial expression systems (Onishi et al., 2011).

In the present work, ansB gene was expressed successfully in E. coli M15 cells after induction with IPTG. The recombinant His-tagged enzyme was purified to homogeneity by Ni-NTA chromatography and displayed a single $\sim 36.0 \mathrm{kDa}$ band on $12 \%$ SDS-PAGE. This value is very close to $34.57 \mathrm{kDa}$ calculated theoretically from the deduced amino acids sequence by ProtParam tool. Slightly larger molecular weight appearing on SDS-PAGE could be due to the presence of His-tag at the N-terminal of the enzyme. These results agree with previously published data indicating that molecular weight of various recombinant L-ASNases on SDS-PAGE ranged from 34 to $37 \mathrm{kDa}$ (Cappelletti et al., 2008 and Liu et al., 2013). It has been suggested that bacterial L-ASNases are homotetramers with molecular mass in the range $140-150 \mathrm{kDa}$ with a highly conserved overall fold. These four identical subunits were with molecular weight of $35 \mathrm{kDa}$ per subunit and bound mainly by non-covalent forces (Kozak et al., 2002 and Wikman et al., 2005).

In this study, the specific activity of the purified His-tagged L-ASNase II was found to be $286 \mathrm{U} / \mathrm{mg}$. This value is close to the specific activity of E. coli native L-ASNase (Zhang et al., 2004; Narta et al., 2007). This result suggests that the expressed recombinant enzyme was fully functional and its activity was not affected by presence of the His-tag. Thus there was no need to remove the $\mathrm{N}$ terminal His-tag from the final product because it did not deactivate the enzyme. It has been suggested that His-tag rarely interferes with the structure and function of target proteins, hence no necessity to be removed (Hamdane et al., 2010 and Ralph et al., 2011). In a previous study, recombinant His-tagged LASNase II from E. coli was purified in a single step using Ni-NTA affinity chromatography and the specific activity of the purifies enzyme was $190 \mathrm{U} / \mathrm{mg}$ (Khushoo et al., 2004).

The influence of temperature on recombinant L- ASNase II activity was assayed in the range from 30 to $80^{\circ} \mathrm{C}$. Temperature activity profile showed that the enzyme was active in wide temperature range with maximum activity at $40^{\circ} \mathrm{C}$. This value has been reported as the optimum temperature of various LASNases (Youssef and Al-Omair, 2008 and Singh et al., 2013). Optimum temperature of recombinant L-ASNase II from E. coli MTCC 739 was at $37^{\circ} \mathrm{C}$ (Vidya et al., 2011). Regarding pH activity, recombinant L- ASNase II was found active over a broad $\mathrm{pH}$ range (4-10) with maximum activity at $\mathrm{pH} 7$ to 8 . These results agree with previously published data indicating that optimum $\mathrm{pH}$ of L-ASNase is ranging from 6 to 8 (Pokrovskaya et al., 2012; Vidya and Pandey, 2012).

In this study, thermal stability was assessed by incubation of recombinant enzyme at 40 to $80^{\circ} \mathrm{C}$ in phosphate buffer for $60 \mathrm{~min}$. L-ASNase exhibited

Egypt. J. Bot., Vol. 56, No. 3 (2016) 
thermal stability with about $81 \%$ of activity retention after $60 \mathrm{~min}$ at $50^{\circ} \mathrm{C}$. Likewise, wild-type L-ASNase II from E. coli DH5 $5_{\alpha}$ retained $71 \%$ of its initial activity after $60 \mathrm{~min}$ incubation at $50^{\circ} \mathrm{C}(\mathrm{Li}$ et al., 2007). In the present investigation, N-terminal His-tagged L-ASNase II retained about $44 \%$ of its initial activity after $60 \mathrm{~min}$ at $60^{\circ} \mathrm{C}$. This thermal stability was found to be much greater than that of C-terminal His-tagged L-ASNase II from E. coli MTCC 739 which decreased to less than $10 \%$ in $1 \mathrm{hr}$ of incubation at $60^{\circ} \mathrm{C}$ (Vidya et al., 2011). These results suggest that N-terminal His-tagged L-ASNase II could be more stable at elevated temperatures compared to C-terminal His-tagged LASNase II.

In order to evaluate the cytotoxic activity of L-ASNase against cancer cell line, MTT assay was conducted. This assay is a simple, precise and rapid method to detect living cells in mammalian cell cultures. Evaluation of the cytotoxic activities of different L-ASNases against different cancer cell lines using MTT assay was well documented (Tesfai et al., 2012).

Findings from this study clearly demonstrated that recombinant His-tagged L-ASNase is highly effective against human myeloid leukemia cell line (HL-60). LCS decreased to about $52 \%, 14 \%$ and $3 \%$ when increased levels of the recombinant enzyme $(0.1,1.0$ and $2 \mathrm{U} / \mathrm{ml}$, respectively) were applied. The enzyme inhibited the growth of HL-60 cell line with $\mathrm{IC}_{50}$ value of $0.14 \pm 0.03$ $\mathrm{U} / \mathrm{ml}$. These results concur with those reported by Abakumova et al. (2009) who evaluated the cytotoxic activity of recombinant L-ASNase from Yersinia pseudotuberculosis using MTT assay and recorded $\mathrm{IC}_{50}$ value of $0.2 \mathrm{U} / \mathrm{ml}$.

By comparing effectiveness of recombinant L-ASNases from various sources one can observe that L-ASNase from E. coli MG27 exhibits higher activity in suppression of human myeloid leukemia cell line (HL-60) than the enzyme from Helicobacter pylori CCUG 17874 reported by Cappelletti et al. (2008). IC $_{50}$ value of recombinant L-ASNase from $E$. coli $\mathrm{MG} 27$ was $0.14 \pm 0.03 \mathrm{U} / \mathrm{ml}$ whereas in the case of recombinant L-ASNase from Helicobacter pylori CCUG 17874 was $3.4 \mathrm{U} / \mathrm{ml}$. The anti-neoplastic activity of L-ASNase based on the dependence of certain tumor cells on an extracellular supply of L-asparagine. Unlike normal cells, neoblastic cells can not synthesize L-asparagine due to their deficiency in L-asparagine synthetase (Moola et al., 1994). Thus, depletion of the circulating pools of L-asparagine by L-ASNase leads to the destruction of the tumor cells, since they are unable to complete protein synthesis.

The findings of the present work revealed that recombinant His-tagged Lasparaginase II was expressed as a functional enzyme, showing feasible thermal stability and was found to be active over broad ranges of temperatures and $\mathrm{pH}$. Furthermore, it exhibited a significant inhibitory effect against leukemic cells suggesting that it could be a promising agent for both therapeutic and industrial applications. Future investigations are aimed for optimization of the expression process to maximize the product at bioreactors level.

Egypt. J. Bot., Vol. 56, No. 3 (2016) 


\section{References}

Abakumova, O.Y., Podobed, O.V., Borisova, A.A., Sidoruk, K.V., Aleksandrova, S.S., Omel'ianiuk, N.M., Pokrovskaia, M.V., Kondakova, L.I. and Sokolov, N.N. (2009) Antitumor Activity of L-Asparaginase from Yersinia pseudotuberculosis. Biochemistry (Moscow) Supplement Series B: Biomedical Chemistry, 3, 198-201.

Cappelletti, D., Chiarelli, L.R., Pasquetto, M.V., Stivala, S., Valentini, G., and Scotti, C. (2008) Helicobacter pylori L-asparaginase: A promising chemotherapeutic agent. Biochemical and Biophysical Research Communications, 377, 1222-1226.

Duval, M., Suciu, S., Ferster, A., Rialland, X., Nelken B., Lutz, P., Benoit, Y., Robert, A., Manel, A.M., Vilmer, E., Otten, J. and Philippem, N. (2002) Comparison of Escherichia coli-asparaginase with Erwinia-asparaginase in the treatment of childhood lymphoid malignancies: results of a randomized European organization for research and treatment of cancer-children's leukemia group phase 3 trial. Blood, 99 , 2734-2739.

Feng, G., Hu, D., Yang, L., Cui, Y., Cui, X.A. and Li, H. (2010) Immobilized-metal affinity chromatography adsorbent with paramagnetism and its application in purification of histidine-tagged proteins. Separation and Purification Technology, 74, 253-260.

Güssow, D. and Clackson, T. (1989) Direct clone characterization from plaques and colonies by the polymerase chain reaction. Nucleic Acids Res, 17, 4000.

Hamdane, D., Skouloubris, S., Myllykallio, H. and Golinelli-Pimpaneau, B. (2010) Expression and purification of untagged and histidine-tagged folate-dependent tRNA:m5U54 methyltransferase from Bacillus subtilis. Protein Expression and Purification, 37, 83-89.

Hüser, A., Klöppner, U. and Röhm, K.H. (1999) Cloning, sequence analysis, and expression of ansB from Pseudomonas fluorescens, encoding periplasmic glutaminase/asparaginase. FEMS Microbiol Lett, 178, 327-335.

Jerlstörm, P.G., Bezjak, D.A., Jennings, M.P. and Beacham, I.R. (1989) Structure and expression in Escherichia coli $\mathrm{K}-12$ of the L-asparaginase I-encoding ansA gene and its flanking regions. Gene., 78, 37-46.

Jia, M., Xu, M., He, B. and Rao, Z. (2013) Cloning, expression, and characterization of L-asparaginase from a newly isolated Bacillus subtilis B11-06. J. Agric Food Chem, 61, 9428-9434.

Khushoo, A., Pal, Y., Singh, B.N. and Mukherjee, K.J. (2004) Extracellular expression and single step purification of recombinant Escherichia coli L-asparaginase II. Protein Expression and Purification, 38, 29-36.

Kotzia, G.A. and Labrou, N.E. (2005) Cloning, expression and characterization of Erwinia carotovora L-asparaginase. J. Biotechnol, 119, 309-323.

Kotzia, G.A. and Labrou, N.E. (2007) L-Asparaginase from Erwinia chrysanthemi, Cloning, expression and characterization. Journal of Biotechnology, 127, 657-669.

Egypt. J. Bot., Vol. 56, No. 3 (2016) 
Kozak, M., Borek, D., Janowski, R. and Jaskólski, M. (2002) Crystallization and preliminary crystallographic studies of five crystal forms of Escherichia coli Lasparaginase II (Asp90Glu mutant). Acta Crystallogr D. Biol. Crystallogr, 58, 130-132.

Kukurová, K., Ciesarová, Z., Mogol, B.A., Açar, Ö.Ç. and Gökmen, V. (2013) Raising agents strongly influence acrylamide and HMF formation in cookies and conditions for asparaginase activity in dough. Eur. Food Res. Technol., 237: 1-8.

Li, Liang-Zhu, Xie Tian-Hong, Li, Hong-Jun, Qing, C, Zhang, Guang-Ming and Sun Mao-Sheng (2007) Enhancing the thermostability of Escherichia coli 1-asparaginase II by substitution with pro in predicted hydrogen-bonded turn structures. Enzyme and Microbial Technology, 41, 523-527.

Liu, Y., Pietzsch, M. and Ulrich, J. (2013) Purification of L-asparaginase II by crystallization. Frontiers of Chemical Science and Engineering, 7, 37-42.

Moola, Z.B., Scawen, M.D., Atkinson, T. and Nicholls, D.J. (1994) Erwinia chrysanthemi L-asparaginase: epitope mapping and production of antigenically modified enzymes. Biochem, J., 302, 921-927.

Mosmann, T. (1983) Rapid colormetric assay for cellular growth and survival application to proliferation and cytotoxicity assays. J. Immunol Methods. 65, 55-63.

Narta, U.K., Kanwar, S.S. and Azmi, W. (2007) Pharmacological and clinical evaluation of L-asparaginase in the treatment of leukemia. Crit Rev Oncol/Hematol, 61, 208-221.

Onishi, Y., Yano, S., Thongsanit, J., Takagi, K., Yoshimune, K. and Wakayama, M. (2011) Expression in Escherichia coli of a gene encoding type II l-asparaginase from Bacillus subtilis, and characterization of its unique properties. Annals of Microbiology, 61, 517-524.

Pedreschi, F., Kaack K. and Granby K. (2008) The effect of asparaginase on acrylamide formation in French fries. Food Chemistry, 109, 386-392.

Pieters. R., Loonen. A.H., Huismans. D.R., Broekema. G.J., Dirven. M.W., Heyenbrok. M.W., Hählen. K. and Veerman. A.J. (1990) In vitro drug sensitivity of cells from children with leukemia using the MTT assay with improved culture conditions. Blood, 76, 2327-2336.

Pokrovskaya, M.V., Aleksandrova, S.S., Pokrovsky, V.S., Omeljanjuk, N.M., Borisova, A.A., Anisimova, N.Y. and Sokolov, N.N. (2012) Cloning, expression and characterization of the recombinant Yersinia pseudotuberculosis L-asparaginase. Protein Expression and Purification, 82, 150-154.

Rabbani, S., Jiang, X., Schwardt, O. and Ernst, B. (2010) Expression of the carbohydrate recognition domain of FimH and development of a competitive binding assay. Anal Biochem, 407, 188-195.

Ralph, E.C., Xiang, L., Cashman, J.R. and Zhang, J. (2011) His-tag truncated butyrylcholinesterase as a useful construct for in vitro characterization of wild-type and variant butyrylcholinesterases. Protein Expression and Purification, 80, 22-27.

Egypt. J. Bot., Vol. 56, No. 3 (2016) 
Sambrook, J. and Russell, D.W. (2001) "Molecular Cloning: A Laboratory Manual". $3^{\text {rd }}$ ed. Cold Spring Harbor (NY): Cold Spring Harbor Laboratory Press.

Shuguo, H., Wei, Z., Chao, Z. and Daoji, W. (2012) One-step expression and tyrosine O-sulfonation of Ax21 in Escherichia coli. Appl Biochem Biotechnol, 166, 1368-1379.

Singh, Y., Gundampati, R.K., Jagannadham, M.V. and Srivastava, S.K. (2013) Extracellular L-asparaginase from a protease-deficient Bacillus aryabhattai ITBHU02: purification, biochemical characterization, and evaluation of antineoplastic activity in vitro. Appl. Biochem. Biotechnol. 171, 1759-1774.

Sockolosky, J.T. and Szoka, F.C. (2013) Periplasmic production via the pET expression system of soluble, bioactive human growth hormone. Protein Expression and Purification, 87,129-135.

Sreenivasulu, V., Jayaveera, K.N. and Rao, P.M. (2009) Optimization of process parameters for the production of L-asparaginase from an isolated fungus. Research $J$. Pharmacognosy and Phytochemistry, 1, 30-34.

Sugimoto, N., Igarashi, K. and Samejima, M. (2012) Cellulose affinity purification of fusion proteins tagged with fungal family 1 cellulose-binding domain. Protein Expression and Purification, 82, 290-296.

Terpe, K. (2003) Overview of tag protein fusions: from molecular and biochemical fundamentals to commercial systems. Appl. Microbiol Biotechnol, 60, 523-533.

Tesfai, Y., Ford, J., Carter, K.W., Firth, M.J., O'Leary, R.A., Gottardo, N.G., Cole, C. and Kees, U.R. (2012) Interactions between acute lymphoblastic leukemia and bone marrow stromal cells influence response to therapy. Leuk Res, 36, 299-306.

Toropova, K., Huffman, J.B., Homa, F.L. and Conway, J.F. (2011) The herpes simplex virus 1 UL17 protein is the second constituent of the capsid vertex-specific component required for DNA packaging and retention. J. Virol 85, 7513-7522.

Vidya, J. and Pandey, A. (2012) Recombinant expression and characterization of Lasparaginase II from a moderately thermotolerant bacterial isolate. Appl. Biochem. Biotechnol, 167, 973-980.

Vidya, J.,Vasudevan, U.M., Soccol, C.R. and Pandey, A. (2011) Cloning, Functional Expression and Characterization of L-Asparaginase II from E. coli MTCC 739. Food Technol. Biotechnol., 49, 286-290.

Wang, Y., Qian, S., Meng, G. and Zhang, S. (2001) Cloning and expression of Lasparaginase gene in Escherichia coli. Appl. Biochem Biotechnol., 95, 93-101.

Wangman, P., Senapin, S., Chaivisuthangkura, P., Longyant, S., Rukpratanporn, S. and Sithigorngul, P. (2012) Production of monoclonal antibodies specific to Macrobrachium rosenbergii nodavirus using recombinant capsid protein. Dis Aquat Organ, 98: 121-131.

Wikman, L.E., Krasotkina, J., Kuchumova, A., Sokolov, N.N. and Papageorgiou, A.C. (2005) Crystallization and preliminary crystallographic analysis of L- 
asparaginase from Erwinia carotovora. Acta Crystallogr. Sect. F Struct. Biol. Cryst. Commun, 61, 407-409.

Youssef, M.M. and Al-Omair, M.A. (2008) Cloning, Purification, Characterization and Immobilization of L-asparaginase II from E. coli W3110. Asian Journal of Biochemistry, 3, 337-350.

Zakalskiy, A.E., Zakalska, O.M., Rzhepetskyy, Y.A., Potocka, N., Stasyk, O.V., Horak, D. and Gonchar, M.V. (2012) Overexpression of (His) 6-tagged human arginase I in Saccharomyces cerevisiae and enzyme purification using metal affinity chromatography. Protein Expression and Purification, 81, 63-68.

Zhang, Y.Q., Tao, M.L., Shen, W.D., Zhou, Y.Z., Ding, Y., Ma Y. and Zhou, W.L. (2004) Immobilization of L-asparaginase on the microparticles of the natural silk sericin protein and its characters. Biomaterials, 25, 3751-3759.

(Received 17/2/2016 accepted 2/3/2016

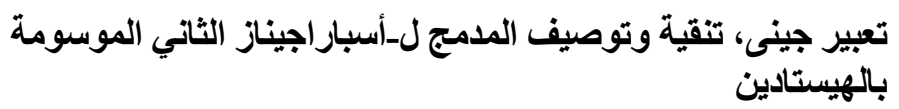

زينات كامل محمد ، شريف التجدى ومحمد جمال قسم علم النبات و الأحياء الدقيقة ، كلية العلوم، جمات جمعة جمال القاهرة، مصر

ألإيشيريشيا كو لاي تنتج اثنين من نظائر انزيمات لـأسبار اجيناز التي تم تعريفها

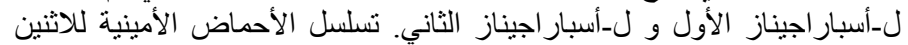

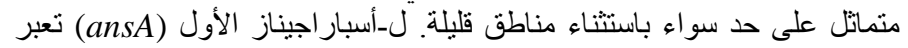

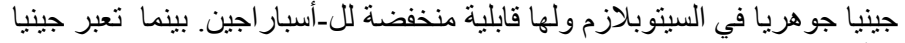

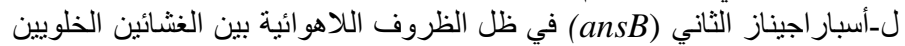

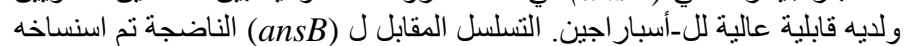

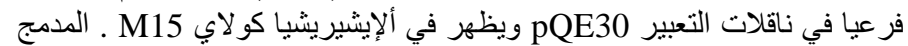

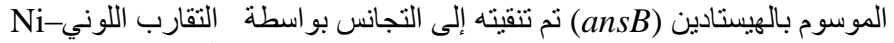
و وعرض •, بr كيلو دالتون على SDS-PAGE.

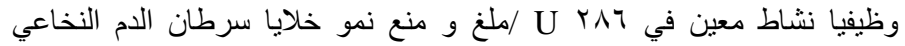

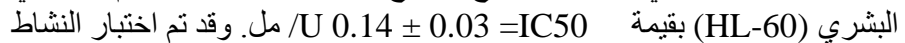

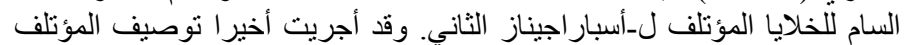
ل-أسبار اجيناز الثاني. 